\title{
PENGARUH MEDIA SIKAKIMI (SILANG KATA KIMIA) TERHADAP HASIL BELAJAR SISWA PADA MATERI STRUKTUR ATOM DI KELAS X IPA MAN 1 PONTIANAK
}

\author{
Yeni Rahmayana, Eni Enawaty, Lukman Hadi \\ MAN 1 Pontianak \\ Kimia FKIP Universitas Tanjungpura Pontianak \\ Email: yenirahmayana11@gmail.com
}

\begin{abstract}
This study aims to determine where there is as significant difference achievement between those who are tought using Sikakimi Media and without between those who are tought using Sikakimi Media who are the topic structure material and to determine the effect size of Sikakimi an students achievement. To achievement the aims, a quasy experimental design was conducted to classes from populations which consists of four classes where choosen as samples though ramdom sampling technique. The sample were X IPA 1 class as experimental group and X IPA 3 as control group. Acoording to research design, with classes were given a set of test before and after treatment. To achieve the first aim, data tested using U-Man Whitney test and to achieve the second data tested using glass test. Acoording to U-Man Whitney data analysis, probality velue was 0,001 which meant there was a significant difference in achievement between both classes. Acoording to glasses test, the effect size score was 0,76 which mean Sikakimi had 27,64\% in the medium category.
\end{abstract}

Keywords: Media, Sikakimi, Structure Material

\section{PENDAHULUAN}

Mata pelajaran Ilmu Pengetahuan Alam (IPA) ialah mengenai cara untuk mengetahui tentang alam dengan cara sistematis. IPA tidak hanya penguasaan tentang kumpulan pengetahuan fakta-fakta, konsepkonsep atau prinsip saja, tapi juga suatu proses penemuan. Salah satu pelajaran dalam cabang IPA yaitu kimia. Pelajaran kimia yang telah diberikan di sekolah diharapkan mampu meningkatkan pemahaman siswa terhadap konsep, prinsip, hokum dan teori kimia serta mampu menerapkannya dalam penyelesaian masalah di kehidupan (Permedikbud No.20 tahun 2016).

Salah satu pokok bahasan materi yang sulit dipahami dan penyebab peningkatan hasil belajar siswa rendah ialah materi struktur atom. Pokok bahasan yang membahas hal-hal abstrak kemudian hafalan seperti materi struktur atom dan table periodic unsur merupakan salah satu materi yang sulit dipelajari dan dimengerti siswa jika hanya dipelajari dalam bentuk gambar dua dimensi (Sari dkk, 2014). Hal tersebut diperkuat oleh nilai ulangan harian 
siswa kelas X IPA tahun pelajaran 2018/2019 di MAN 1 Pontianak yang disajikan pada Tabel 1 ..

Tabel 1. Persentase Ketuntasan Rat-rata Nilai Ulangan Harian Siswa Kelas X di MAN 1 Pontianak Materi Struktur Atom Tahun Ajaran 2018/2019

\begin{tabular}{|c|c|c|c|c|}
\hline \multicolumn{3}{|c|}{ Jumlah Siswa } & \multicolumn{2}{|c|}{$\begin{array}{c}\text { Persentase } \\
(\%)\end{array}$} \\
\hline $\begin{array}{c}\text { Kel } \\
\text { as }\end{array}$ & $\begin{array}{c}\text { Tunt } \\
\text { as }\end{array}$ & $\begin{array}{c}\text { Tida } \\
\text { k } \\
\text { Tunt } \\
\text { as } \\
\end{array}$ & $\begin{array}{c}\text { Tunt } \\
\text { as }\end{array}$ & $\begin{array}{c}\text { Tida } \\
\mathbf{k} \\
\text { Tunt } \\
\text { as } \\
\end{array}$ \\
\hline $\begin{array}{c}\mathbf{X} \\
\text { MIP } \\
\text { A } 1\end{array}$ & 1 & 35 & $\begin{array}{c}2,78 \\
\%\end{array}$ & $\begin{array}{c}97,22 \\
\%\end{array}$ \\
\hline $\begin{array}{c}\text { X } \\
\text { MIP } \\
\text { A } 2\end{array}$ & 2 & 34 & $\begin{array}{c}5,56 \\
\%\end{array}$ & $\begin{array}{c}94,44 \\
\%\end{array}$ \\
\hline
\end{tabular}

Dari tabel 1. menunjukkan bahwa hasil belajar kimia kelas X MAN 1 Pontianak masih tergolong rendah.

Berdasarkan dari wawancara singkat guru terhadap hasil belajar siswa, rendahnya nilai siswa karena siswa belum mampu memahami konsep-konsep kimia dan kurang tertarik mengikuti pembelajaran terutama pemahaman konsep pada submateri konfigurasi elektron dan bilangan kuantum. Siswa masih sulit menentukan konfigurasi elektron dan bilangan kuantum sehingga hasil belajar siswa rendah. Seperti yang telah diungkapkan oleh Fadiawati dan Liliasari (2009) bahwa bilangan kuantum ialah materi yang menantang dan sulit divisualisasikan, kemudian secara teknik tergolong sulit dan abstrak. Hasil wawancara 3 orang siswa dari masing-masing kelas $\mathrm{X}$ MIPA dengan kemampuan akademik yang berbeda juga menyatakan mereka kesulitan dalam memahami materi konfigurasi elektron dan bilangan kuantum. Kekeliruan dalam memahami jumlah elektron dalam subkulit, suborbital dan konfigurasi elektron menyebabkan siswa salah dalam menentukan bilangan kuantum.

Rendahnya hasil belajar siswa karena guru hanya menggunakan metode ceramah dan diskusi saja selama proses pembelajaran. Apabila siswa hanya menjadi pendengar maka hal ini dapat menimbulkan kebosanan sehingga dapat mempengaruhi hasil belajar yang kurang optimal. Seperti yang diungkapkan oleh Sutaryono, Dkk (2014) bahwa para guru paling sering menggunakan metode ceramah untuk mengajar sehingga menimbulkan kejenuhan bagi siswa. Akibatnya, siswa menjadi kurang aktif dalam pembelajaran.

Observasi pengamatan yang telah dilakukan dikelas $\mathrm{X}$ IPA mengenai pembelajaran di kelas juga menunjukkan siswa kurang aktif dan antusias mengikuti kegiatan pembelajaran di kelas dengan hanya menggunakan metode ceramah dan diskusi. Telah terjadi komunikasi satu arah yang didominasi guru sehingga siswa kesulitan untuk mengeksplorasi materi yang telah dipahami dan diterimanya karena sumber belajar hanya berasal dari yang telah guru sampaikan. Disamping itu, guru juga hanya menggunakan media papan tulis dan spidol serta buku paket LKS pegangan siswa saja.

Wawancara yang telah
dilakukan guru
mengungkapkan bahwa penggunaan media buku paket, papan tulis dan spidol saja untuk mengajar. Sesekali guru menggunakan media powerpoint, dan selebihnya tidak pernah menggunakan media lain 
karena tidak pernah membuat atau mencoba menggunakan media pembelajaran lainnya. Guru mengungkapkan bahwa selain buku paket, diperlukan penunjang seperti media pembelajaran yang dapat meningkatkan hasil belajar siswa dikelas.

Alat komunikasi diperlukan sebagai penunjang dalam proses belajar yang berfungsi untuk suatu pembelajaran. Alat komunikasi tersebut dapat berupa media pembelajaran. Hamalik (2011) mengungkapkan bahwa selama proses pembelajaran, beberapa alat, metode, dan teknik merupakan media pembelajaran yang dapat dipergunakan untuk mengefektifkan komunikasi dan interaksi antara guru dan siswa. Media yang akan digunakan juga harus memperhatikan kebutuhan dan kemampuan siswa. Beberapa factor lain yang juga harus diperhatikan yaitu kemampuan dan keterampilan awal serta tingkat senang siswa (Arsyad, 2011) pengemasan media yang menarik, mudah dimengerti dan melibatkan siswa secara langsung satu diantaranya yakni dengan menggunakan Sikakimi (Silang Kata Kimia).

Media pembelajaran Sikakimi adalah media permainan teka teki silang. Agar siswa tertarik untuk belajar, media ini dirancang sedemikian rupa sehingga siswa tertarik untuk belajar dan tujuan pembelajaranpun tercapai. Berdasarkan pendapat Sasriya, T., Dkk (2016), salah satu media pembelajaran yang dapat mempermudah siswa mengingat dan memahami konsep materi pembelajaran yaitu dengan menggunakan media teka-teki silang. Media ini dipilih karena dapat dikombinasikan dengan metode permainan dan dapat menciptakan suatu pembelajaran yang menyenangkan karena dengan permainan, kegiatan pembelajaran akan semakin menarik dan siswa akan lebih giat belajar sehingga hasil belajar dapat meningkat (Mardati \& Wangid, 2015).

Media Sikakimi digunakan untuk melatih ingatan dan berfikir kritis siswa atas materi yang telah diterima sebelumnya, melatih kerjasama kelompok dalam mengisi kotak-kotak kosong dengan kata-kata yang benar dan melatih daya piker siswa sehingga siswa menjadi lebih aktif dalam berdiskusidan ingatan serta pemahaman mengenai materi lebih kuat. Selain itu, media Sikakimi dapat melatih kecermatan dalam memilih kata dan mencari jawaban yang benar agar tidak salah menempatkan huruf karena salah penempatan huruf dalam kotak maka tidak dapat menemukan jawaban dari soal yang lainnya. Seperti yang dikatakan oleh Rabiah \& Nurjannah dalam Fathonah, Dkk (2013) bahwa peningkaatan motivasi siswa dalam menjawab soal ialah dengan menggunakan media TTS, kemudian dengan adanya permainan memberikan peningkatan kerjasama yang sehat kepada siswa, memberi rangsangan siswa berfikir kritis dan kreatif, serta menuntut siswa untuk lebih teliti lagi.

Selain itu, penelitian dari Rani Fathonah S, Dkk (2013) menunjukkan bahwa prestasi belajar kognitif siswa menggunakan media TTS yaitu 16,81 sehingga lebih tinggi dibandingkan media Kartu 12,97 pada 
pembelajaran kimia melalui pendekatan CTL pada materi zat adiktif dan psikotropika; Prestasi belajar afektif siswa menggunakan media TTS 72,38 lebih tinggi dibandingkan media Kartu 69,26 pada pembelajaran kimia melalui pendekatan CTL pada materi zat adiktif dan psikotropika.

\section{METODE PENELITIAN}

Bentuk penelitian yang digunakan dalam penelitian ini ialah eksperimen semu (quasy experimental design). Rancangan yang digunakan ialah nonequivalent control group design yaitu eksperimen yang mempunyai kelompok kontrol, namun tidak dapat berfungsi sepenuhnya untuk mengontrol variabel luar yang mempengaruhi eksperimen (Sugiyono, 2016). Pada penelitian ini, kelas kontrol diberikan perlakuan tanpa menggunakan media Sikakimi, sedangkan kelas eksperimen diberikan perlakuan menggunakan media Sikakimi. Populasi dalam penelitian ini yaitu kelas X MIPA 1, X MIPA 2 dan X MIPA 3. Pemilihan sampel dilakukan dengan melakukan uji statistik bartlett dan diperoleh sig sebesar 0.224 yang berarti sampel homogen. Teknik pengambilan sampel yaitu random sampling dengan cara melakukan pengundian dan diperoleh kelas X MIPA 1 yaitu sebagai kelas eksperimen dan Kelas X MIPA 3 sebagai kelas kontrol. Terdapat tiga tahap dalam melakukan penelitian ini, yakni tahap persiapan, tahap pelaksanaan dan tahap akhir.

Melakukan tahap persiapan yaitu: 1) Melakukan pra-riset berupa pengumpulan data nilai nilai siswa, diskusi, dan wawancara dengan guru mata pelajaran kimia; 2) Identifikasi masalah penelitian dari hasil prariset yang telah didapat; 3) Memberikan solusi pembelajaran yaitu dengan menggunakan media Sikakimi; 4) Membuat perangkat pembelajaran berupa Rencana Pelaksanaan Pembelajaran (RPP) dan media Sikakimi; 5) Membuat instrumen penelitian dan pedoman wawancara; 6) Melakukan validasi perangkat pembelajaran RPP, media Sikakimi dan instrumen penelitian; 7) Apabila RPP, media, dan instrumen penelitian dinyatakan tidak valid oleh validator, maka langkah selanjutnya adalah merevisi RPP, media dan instrumen penlitian tersebut; 8) Melakukan uji coba instrumen kepada siswa kelas XI IPA; 9) Menganalisis hasil uji coba instrumen untuk mengetahui tingkat reliabilitas soal; 10) Menentukan kelas kontrol dan eksperimen sebagai sampel penelitian.

Melakukan tahapan pelaksanaan yaitu; 1) Menentukan kelas eksperimen dan kelas kontrol sebagai sampel penelitian; 2) Memberikan soal pretest terhadap kelas eksperimen dan kelas kontrol; 3) Memberikan perlakukan terhadap kelas eksperimen dengan menggunakan media Sikakimi dan kelas kontrol tanpa menggunakan media Sikakimi dan disertai adanya observer sebagai evaluator; 4) Memberikan soal posttest terhadap kelas eksperimen dan kelas kontrol; 5) Melakukan wawancara langsung kepada siswa yang berkemampuan tinggi, sedang, dan rendah untuk mengumpulkan data.

Melakukan tahap akhir yaitu; 1) Melakukan analisis dan pengolahan data hasil penelitian pada kelas kontrol dan kelas eksperimen menggunakan uji statistik yang 
sesuai; 2) Membuat pembahasan dan kesimpulan dari hasil penelitian; 3) Menyusun laporan penelitian.

Data pretest dan postest yang telah diperoleh kemudian dianalisis menggunakan uji normalitas data, yakni uji Kolmogorov-Smirnov. Jika data terdistribusi normal, maka dilanjutkan dengan uji $\mathrm{T}$ sampel independen. Jika data tidak terdistribusi normal, maka digunakan uji U-Man Whitney. Untuk mengetahui besarnya pengaruh media Sikakimi terhadap hasil belajar, maka digunakan rumus effect size dari Glass.

\section{HASIL DAN PEMBAHASAN}

Pretest dan Postest Siswa

Setelah siswa diberikan pretest dan posttest, diperoleh hasil secara keseluruhan yang dapat dilihat pada tabel 2 .

Tabel 2 Persentase Ketuntasan Hasil Pretest dan Posttest Kelas Kontrol dan Kelas Eksperimen

\begin{tabular}{c|c|cccc|cccc}
\hline \multirow{2}{*}{ Kelas } & Jumlah & \multicolumn{4}{c|}{ Pretest } & \multicolumn{4}{c}{ Posttest } \\
\cline { 3 - 10 } Kontrol & Siswa & T & \% & TT & \% & T & \% & TT & \% \\
\hline Eksperimen & 37 & 0 & $0 \%$ & 37 & $100 \%$ & 12 & $32,4 \%$ & 25 & $\begin{array}{c}67,5 \\
\%\end{array}$ \\
\hline
\end{tabular}

Berdasarkan tabel 4.1 bahwa pretest para siswa tidak menghasilkan ketuntasan KKM 75. Sedangkan pada postest, ada 12 siswa $(32,4 \%)$ di kelas kontrol mencapai ketuntasan dan 25 siswa $(65,7 \%)$ di kelas eksperimen yang mencapai ketuntasan dengan nilai KKM 75. Untuk mengetahui ada atau tidak perbedaan hasil belajar kedua kelas maka dilakukan dengan menganalisis nilai pretest dan posttest.

Analisis hasil pretest dengan menggunakan uji normalitas Kolmogorov-Smirnov pada SPSS 17.0. Hasil uji normalitas pretest siswa kelas kontrol dan kelas eksperimen masing-masing yaitu 0,002 dan 0,200. Salah satu kelas terdapat tidak berdistribusi normal, maka dilakukan uji statistik nonparametrik yaitu uji U-Mann Whitney. Hasil uji U-Mann Whitney menunjukkan bahwa Asymp.Sig (2- tailed $)<0,05$ yaitu sebesar 0,079 sehingga Ho diterima. Hasil tersebut menunjukkan bahwa tidak terdapat perbedaan kemampuan awal antara siswa kelas kontrol dan kelas eksperimen, sehingga untuk menentukan perbedaan hasil belajar siswa pada kelas kontrol dan kelas eksperimen digunakan data nilai postest.

Postest diberikan setelah proses pembelajaran berakhir. Hasil nilai postest kemudian dianalisis untuk mengetahui apakah terdapat perbedaan hasil belajar siswa yang diberikan pembelajaran menggunakan media Sikakimi dengan siswa yang tidak diberikan pembelajaran menggunakan media Sikakimi. Hasil postest dianalisis menggunakan uji normalitas Kolmogorov-Smirnov pada SPSS 17.0. Hasil uji normalitas postest siswa kelas kontrol dan kelas eksperimen masing-masing yaitu 
0,053 dan 0,000 Jika salah satu kelas tidak berdistribusi normal, maka dilakukan uji statistik nonparametrik yaitu uji U-Mann Whitney. Hasil uji U-Mann Whitney menunjukkan bahwa Asymp.Sig (2-tailed) $<0,05$ yaitu sebesar 0,001 sehingga Ho ditolak. Hasil tersebut menunjukkan bahwa terdapat perbedaan antara siswa kelas kontrol dan kelas eksperimen yang disebabkan oleh perbedaan perlakuan yang diberikan kepada kedua kelas.

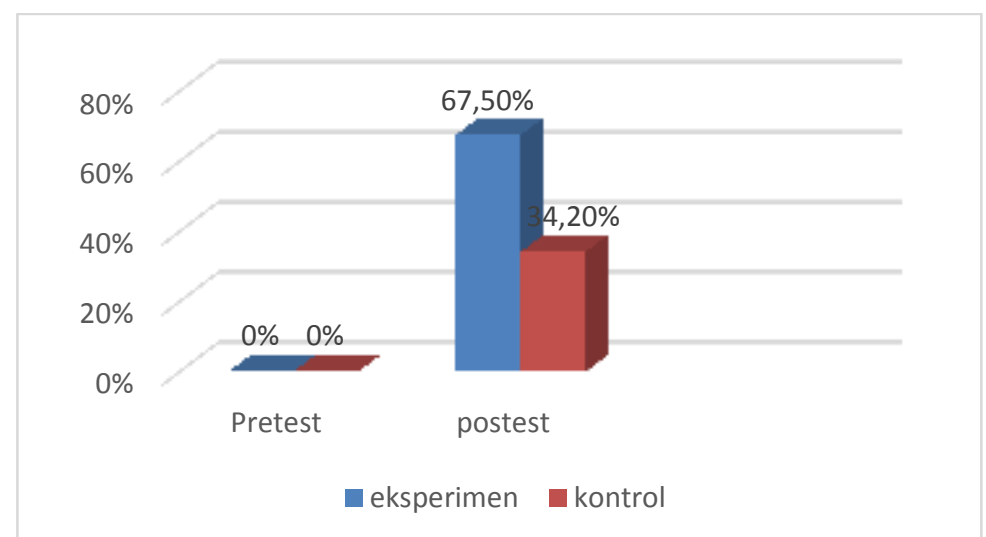

\section{Gambar 1. Jumlah Siswa yang Tuntas dan Tidak Tuntas pada Pretest dan Posttest Kelas Eksperimen dan Kontrol}

Pada Gambar 4.1 menunjukkan setelah diberikan perlakuan nilai postest pada kedua kelas mengalami peningkatan yaitu sebesar $32,4 \%$ pada kelas kontrol dan $65,7 \%$ pada kelas eksperimen. Peningkatan hasil belajar siswa tersebut dikarenakan kedua kelas telah diberi perlakuan. Pada kelas eksperimen, siswa diberi media Sikakimi sebagai media pembelajaran sehingga mempermudah siswa untuk mampu mengingat dan memahami materi akibatnya siswa mampu untuk mengerjakan soal posttest. Hal tersebut sejalan dengan pendapat Sasriya, T., Dkk (2016) media TTS juga dapat mempermudah siswa untuk mengingat dan memahami konsep yang terkandung dalam materi pembelajaran. Hasil wawancara dengan siswa kode IK juga

mengatakan bahwa mampu mengerjakan soal postest karena mengingat cara pengerjaan soal dan jawaban pada media Sikakimi yang telah dikerjakan sebelumnya. Siswa mengungkapkan bahwa teka teki silang pada media Sikakimi membuatnya mampu mengingat kembali materi dan lembar jawaban media yang telah dikerjakan bersama teman kelompoknya membuatnya paham sehingga dapat menyelesaikan soal.

Sedangkan di kelas kontrol banyak siswa yang tidak tuntas. Hal tersebut dikarenakan pada kelas kontrol tidak menggunakan media pembelajaran Sikakimi sehingga siswa sulit dalam menentukan 
konfigurasi elektron dan bilangan kuantum. Berdasarkan wawancara dengan siswa kode EN mengatakan dalam memahami keempat bilangan kuantumnya sehingga dalam penentuannya menjadi salah. Sejalan dengan pendapat Fadiawati dan Liliasari (2009) bilangan kuantum ialah materi yang secara abstrak, maupun teknik sulit divisualisasikan dan menantang.

\section{Proses Pembelajaran di Kelas Kontrol dan Kelas Eksperimen}

Pada kelas kontrol dilakukan proses pembelajaran dengan diskusi kelompok tanpa menggunakan media Sikakimi dan pada kelas eksperimen siswa menggunakan metode diskusi dengan media Sikakimi. Kegiatan diskusi diawali dengan menempatkan siswa pada kelompoknya masingmasing yang telah dibagikan secara heterogen dan mengerjakan soal selama 40 menit. Dengan menggunakan metode diskusi, aktivitas di kelas dapat berlangsung secara aktif dan siswa dalam satu kelompok dapat saling membantu dalam menyelesaikan tugas yang diberikan. Namun, pada kenyataannya, pada kelas kontrol tidak semua siswa aktif di dalam kelas.

Hasil dari pengamatan saat pembelajaran berlangsung di kelas kontrol, siswa terlihat kesulitan dalam mengerjakan soal yang diberikan. Proses diskusi didalam kelompok hanya dilakukan oleh beberapa siswa saja. Siswa lainnya hanya terlihat diam dan menunggu bahkan terdapat beberapa siswa yang bermain dengan temannya sehingga pada saat waktu pengumpulan jawaban beberapa kelompok tidak selesai menjawab soal yang diberikan. Hal tersebut disebabkan siswa tidak bekerjasama selama proses diskusi. Slavin (2008) mengungkapkan bahwa jika anggota kelompok tidak disiplin maka menjadi tidak kondusif. Sikap tidak disiplin yang dimaksudkan yakni siswa tidak membantu teman sekelompoknya mengerjakan tugas yang diberikan. Guru sebagai fasilitator membimbing siswa untuk melakukan diskusi dan menegur siswa yang tidak bekerjasama dengan teman kelompoknya serta membimbing siswa untuk mengerjakan soal diskusi. Hal tersebut searah dengan peran guru yang diungkapkan oleh Sardiman (2008) bahwa peran guru diantaranya sebagai fasilitator, informator, motivator dan pengarah/.

Wawancara dengan siswa di kelas kontrol mengatakan bahwa dalam proses pembelajaran, siswa yang berkemampuan tinggilah yang lebih banyak mengerjakan soal yang diberikan. Hal tersebut terjadi karena siswa yang berkemampuan rendah kesulitan dalam memahami materi dan merasa sudah ada temannya yang mengerti materi sehingga bergantung pada temannya tersebut. Siswa mengungkapkan bahwa kegiatan diskusi yang dilakukan juga terasa membosankan. Kegiatan diskusi yang dilakukan juga sudah biasa dilakukan oleh siswa sehingga siswa merasa tidak begitu tertarik dengan kegiatan pembelajaran yang dilakukan. Hal tersebut sejalan dengan pendapat Hakim (2004) yang mengatakan bahwa metode belajar yang tidak bervariasi dan suasana belajar yang tidak berubah-ubah dapat menyebabkan siswa tidak tertarik dalam belajar. 
Berbeda dengan kelas eksperimen. Pada kelas ini guru menggunakan media Sikakimi sebagai media pembelajaran. Media Sikakimi ini terdiri dari satu lembar soal-soal yang jawabannya berisi kotak teka-teki silang, mendatar dan menurun dari materi bilangan kuantum, suborbital dan konfigurasi elektron serta lembaran jawabannya dan terdapat amplop soal yang berisi soal-soal yang harus dikerjakan masing-masing kelompok dipapan tulis. Berikut ini contoh media pembelajaran Sikakimi:
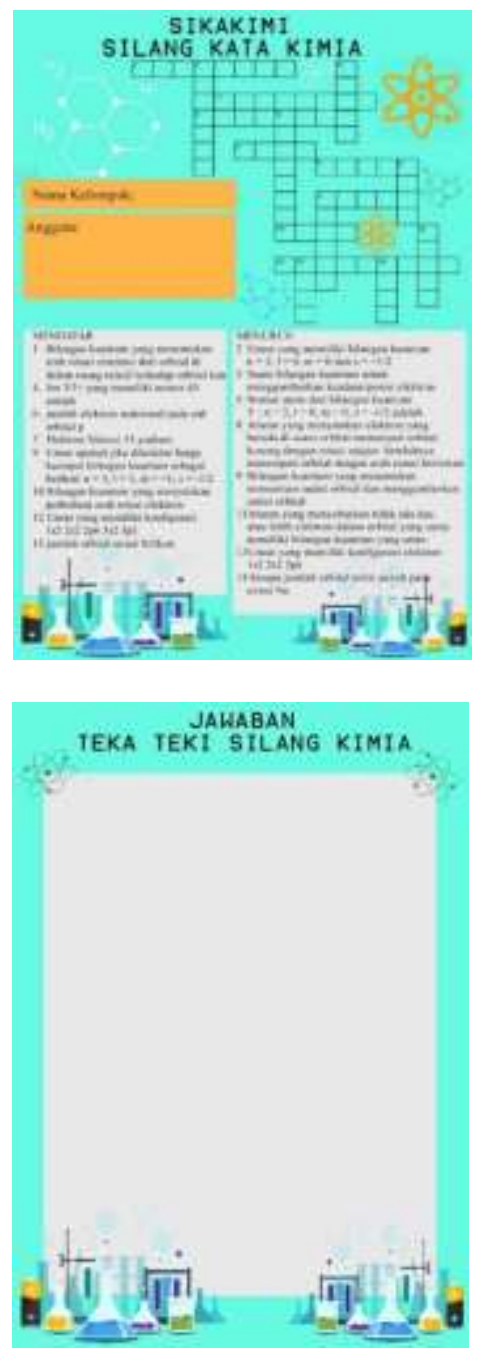

Gambar 2. Media Sikakimi
Berdasarkan wawancara siswa IK dan S, media Sikakimi sangat membantu siswa untuk mengingat serta memahami materi. Siswa juga mengatakan bahwa kotak silang kata kimia dapat mempermudah siswa dalam menjawab pertanyaan sehingga dalam diskusi kelompok dapat meningkatkan kerjasama dan siswa dapat dengan cepat untuk menentukan jawabannya, menuntut untuk berpikir kritis serta teliti dalam mengisi jawaban. Seperti yang dikatakan Rabiah \& Nurjannah (dalam Fathonah, dkk 2013) bahwa keuntungan dari penggunaan media TTS diantaranya ialah mampu memberi peningkatan kerja sama yang sehat kepada siswa, memberi rangsang pada kepada siswa untuk berpikir kritis dan kreatif, serta menuntut siswa untuk lebih teliti menyelesaikan soal. Siswa juga mengungkapkan bahwa adanya permainan sederhana seperti kotak silang kata dan pertanyaan pada media tersebut cepat dalam mengingat materi yang telah disampaikan. Sejalan dengan pendapat Aqib (2002) melalui permainan, pembelajaran dapat memberi pengalaman menarik bagi siswa dalam mengenal dan memahami suatu konsep.

Menurut siswa, adanya warna dan gambar dalam media Sikakimi juga membuat siswa tertarik untuk mengerjakan soal sehingga materi yang diberikan lebih mudah untuk diingat (Lampiran wawancara). Seperti pendapat Suwaryantini, dkk (2014) mengungkapkan adanya media bergambar dan berwarna dapat membantu guru dalam memberi penyampaian materi kepada siswa, materi yang mudah dimengerti, lebih 
menarik dan lebih menyenangkan bagi siswa.

Selama proses diskusi juga terdapat hampir semua kelompok aktif dalam bertanya kepada guru mengenai soal dan pengisian jawaban media Sikakimi. Guru memberikan bantuan dengan memberi penjelasan kepada kelompok yang belum memahami materi dan mengisi jawaban pada media. Hal tersebut sesuai dengan peran seorang guru yang diungkapkan oleh Sardiman (2008) bahwa peran guru antara lain sebagai fasilitator, informator dan pengarah/director.

Setelah rangkaian proses pembelajaran selesai, memberikan penghargaan setelah menghitung jumlah jawaban yang diperoleh masing-masing kelompok. Adanya penghargaan tersebut dapat memberi rasa puas serta bangga pada siswa selama kegiatan pembelajaran dan kebanggaan tersebut menjadi penguat bagi siswa untuk mencapai keberhasilan berikutnya. Hal tersebut sejalan dengan pendapat Hamalik (2013) yang mengungkapkan bahwa memberi pujian/penghargaan pada siswa untuk hal yang telah dilakukannya dengan berhasil maka akan besar manfaatnya sebagai pendorong belajar.

\section{Perhitungan Effect Size}

Hasil perhitungan memperoleh nilai ES dari rumus effect size yaitu 0,76. Hasil tersebut tergolong dalam kategori sedang. Berdasarkan tabel Z, persentase pengaruh media Sikakimi terhadap peningkatan hasil belajar siswa sebesar 0,2764. Jadi, dalam penelitian ini memberi pengaruh sebesar $27,64 \%$ terhadap peningkatan hasil belajar. Hal tersebut bearti bahwa menggunakan media Sikakimi memberikan pengaruh terhadap pembelajaran dengan peningkatan hasil belajar siswa.

\section{SIMPULAN DAN SARAN Simpulan}

Berdasarkan hasil penelitian yang telah dilakukan, diperoleh simpulan yaitu ada perbedaan hasil belajar siswa kelas X IPA MAN 1 Pontianak yang diajar menggunakan media Sikakimi dengan siswa yang diajar tanpa menggunakan media Sikakimi dan pembelajaran dengan menggunakan media Sikakimi memberikan pengaruh sebesar $27,64 \%$ dengan kategori sedang terhadap peningkatan hasil belajar siswa kelas X IPA MAN 1 Pontianak. Saran

Terdapat saran yang peneliti beri terkait penelitian yang telah dilakukan yakni diharapkan kepada guru atau peneliti yang akan menggunakan media Sikakimi yaitu memberikan penjelasan yang jelas mengenai langkah-langkah permainan agar siswa tidak kebingungan ataupun keliru selama proses kegiatan berlangsung serta guru harus lebih melakukan kontrol dan membimbing setiap kelompok untuk mengerjakan media Sikakimi terutama pada sampel yang berjumlah banyak agar setiap siswa terlibat dalam berdiskusi.

\section{DAFTAR RUJUKAN}

Arsyad, A. (2011). Media Pembelajaran. Jakarta: PT. Raja Grafindo Persada.

Aqib, Z. (2002). Profesionalisme Guru dalam Pembelajaran. Surabaya: Insan Cendikia.

Fadiawati, N. \& Liliasari. (2009). Konsepsi Mahasiswa 
Pendidikan Kimia Tahun Pertama Tentang Struktur Atom. Prosiding Seminar Nasional Penelitian, Pendidikan dan Penerapan MIPA. Yogyakarta: UNY.

Fathonah, R., Sugiharto \& Utomo, S. B. (2013). Studi Komparasi Penggunaan Media TekaTeki Silang (TTS) Dengan Kartu Pada Pembelajaran Kimia Melalui Pendekatan Contextual Teaching and Learning (CTL) Terhadap Prestasi Belajar Siswa Pada Materi Zat Adiktif dan Psikotropika Kelas VIII SMPN 2 Ngadirojo. Jurnal Pendidikan Kimia, 2(3), 68-76.

Hakim, T. (2004). Belajar Secara Efektif. Jakarta: Pustaka Pembangunan Swadaya Nusantara.

Hamalik, O. (2013). Proses Belajar Mengajar. Jakarta: Bumi Aksara.

Kemendikbud. (2016). Permendikbud No. 020 Tahun 2016 Tentang Standar Kompetisi Lulusan Pendidikan Dasar dan Menengah. Jakarta: Kemendikbud.

Mardati, A., \& Wangid, M. N. (2015). Pengembangan Media Permainan Kartu Gambar dengan Teknik Make a Match untuk Kelas 1 SD. Jurnal Prima Edukasia, 3(2), 120. https://doi.org/10.2183/jpe. v3i2.6532.
Sardiman, A. M. (2008). Interaksi dan Motivasi Belajar Mengajar. Jakarta: PT. Raja Grafindo Persada.

Sari, R., Saputro, S., \& Catur Saputro, A. (2014). Pengembangan Modul Pembelajaran Kimia Berbasis Blog Untuk Materi Struktur Atom dan Sistem Periodik Unsur SMA Kelas XI. Jurnal Pendidikan Kimia Universitas Sebelas Maret, 3(2), 7-15.

Sasriya, T., Dibia, I, K., \& Kurmariyatni, N. (2016). Penerapan Model Pembelajaran NHT Berbantuan Media TekaTeki Silang untuk Meningkatkan Keaktifan. Mimbar PGSD, 6(3), 1-9.

Slavin, R. E. (2008). Cooperative Learning, Teori, Riset, dan Praktik (terjemah). Bandung: Nusa Media.

Sugiyono. (2016). Metode Penelitian Kuantitatif, Kualitatif, dan $R \& D$. Bandung: Alfabeta.

Sutaryono, S. R., Mulyani, S., \& Dwi Ariani, S. R. (2014). Pembelajaran Kimia dengan Metode Talking Stick Berbantuan Media Flash Dilengkapi Handout untuk Meningkatkan Kualitas Proses dan Hasil Belajar Materi Pokok Ikatan Kimia Siswa Kelas $\mathrm{X}, 4$ SMA Negeri 1 Dayeuhluhur Tahun Ajaran 2010/2011. Jurnal Pendidikan

Kimia 
Jurnal Kajian Pembelajaran dan Keilmuan Vol. 5 No.2, Oktober 2021-Maret 2022

Universitas Sebelas Maret, 3(3), 121-128. 